\title{
Peningkatan kemampuan guru dalam menyusun kelengkapan mengajar melalui in-house training
}

\author{
Yulmi Yulmi*) \\ Sekolah Dasar Negeri 05 Air Pura
}

\begin{tabular}{l} 
Article Info \\
\hline Article history: \\
Received April $14^{\text {th }}, 2021$ \\
Revised May $16^{\text {th }}, 2021$ \\
Accepted Jun $18^{\text {th }}, 2021$ \\
\hline
\end{tabular}

\section{Keyword:}

Kemampuan

Kelengkapan mengajar In-house training

\begin{abstract}
Penelitian dilakukan di UPT SDN 05 Air Pura Kecamatan Air Pura selama kurang lebih dua bulan dimulai tanggal 05 Juli 2020 sampai dengan tanggal 07 Agustus 2020. Pengumpulan data dilakukan melalui angket, observasi dan dokumentasi. Dari angket diperoleh hasil bahwa secara keseluruhan Guru UPT SDN 05 Air Pura Kecamatan Air Pura menyatakan penting untuk memiliki kelengkapan mengajar. Sebagian besar Guru UPT SDN 05 Air Pura Kecamatan Air Pura merasa bahwa pengalaman mengajarnya masih minim pada mata pelajaran yang diajarkan, latar belakang pendidikan tidak begitu sesuai dengan mata pelajaran yang diajarkan dan pengetahuan tentang penyusunan kelengkapan mengajar masih kurang. Seluruh Guru UPT SDN 05 Air Pura Kecamatan Air Pura menghendaki adanya In-House Training penyusunan kelengkapan mengajar dan $100 \%$ Guru memiliki motivasi yang tinggi untuk mengikuti In-House Training dan memiliki keinginan yang kuat untuk membuat kelengkapan mengajar dan akan menggunakan kelengkapan mengajar tersebut sebagai penunjang proses pembelajaran. Penelitian dilakukan sebanyak 2 siklus. Pada siklus 1 diperoleh 42,5\% Guru berhasil menyelesaikan penyusunan kelengkapan mengajar dan pada Siklus 2 terdapat 95\% Guru berhasil menyelesaikan penyusunan kelengkapan mengajar. Jadi ada peningkatan kemampuan Guru dalam menyusun kelengkapan mengajar setelah dilakukan In-House Training tahap 1 dan masing-masing Guru menunjukkan peningkatan yang signifikan. In-House Training adalah salah satu pola yang sangat efektip untuk meningkatkan kemampuan Guru dalam menyusun kelengkapan mengajar.
\end{abstract}

(C) 2021 The Authors. Published by IICET.

This is an open access article under the CC BY-NC-SA license (https://creativecommons.org/licenses/by-nc-sa/4.0

\section{Corresponding Author:}

Yulmi Yulmi

Sekolah Dasar Negeri 05 Air Pura

Email: yulmi@gmail.com

\section{Pendahuluan}

Salah satu masalah pokok yang dihadapi UPT SDN 05 Air Pura Kecamatan Air Pura adalah hasil belajar yang cenderung masih rendah. Hal ini diindikasikan dari rendahnya nilai ujian nasional dan nilai uji kompetensi pada tahun pelajaran 2020/2021 . Untuk meningkatkan prestasi belajar sekolah telah berupaya melalui proses pembelajaran dengan system ganda sesuai KTSP yaitu di sekolah dan telah melalui proses penilaian secara berkelanjutan oleh pendidik dalam hal ini Guru. Namun demikian tetap saja prestasi belajar peserta didik saat dievaluasi baik ulangan harian, ulangan tengah semester maupun ulangan akhir semester menurut data yang diinventarisir oleh bagian kurikulum masih cenderung rendah dan belum memuaskan. Rata-rata siswa yang dapat tuntas sesuai KKM berkisar antara 50 - 60\%, sedangkan sisanya untuk menuntaskan harus menempuh remedial. 
Keberhasilan sebuah pembelajaran setidaknya dipengaruhi oleh 5 komponen kunci, yaitu: (1) Guru, (2) Sumber dan Media Belajar, (3) Lingkungan, (4) Siswa dan (5) proses pembelajaran. Guru dalam pembelajaran memiliki peran yang sangat strategis karena akan berkaitan dengan pengelolaan 4 komponen kunci lainnya. Bahkan dalam konsep tentang sumber belajar yang ditulis oleh Sudjarwo dikutip oleh (Rahmat Saripudin,2008) guru dapat dikategorikan sebagai sumber belajar.

Atas dasar hal tersebut dalam upaya meningkatkan mutu pembelajaran, UPT SDN 05 Air Pura Kecamatan Air Pura berkomitmen untuk: meningkatkan mutu Guru karena Guru merupakan salah satu kunci keberhasilan proses pendidikan. Ditangan Guru-lah cita-cita pembangunan, pendidikan nasional, kurikulum nasional, visi-misi lembaga penyelenggara pendidikan hingga visi-misi sekolah dapat terwujud. Guru yang baik akan mampu mengoptimalkan seluruh potensi sumber dan media belajar yang ada di lingkungannya untuk pembelajaran yang optimal. Dengan mengacu kepada strategisnya peran guru pada sebuah lembaga pendidikan maka UPT SDN 05 Air Pura Kecamatan Air Pura memberikan perhatian yang besar bagi terwujudnya Guru professional.

Untuk mewujudkan guru yang profesional sehingga mampu meningkatkan kompetensi dan mutu Guru yang bersangkutan, maka UPT SDN 05 Air Pura Kecamatan Air Pura merancang program program dan kegiatan yang mengarah pada peningkatan mutu Guru misalnya dengan mengikutsertakan Guru dalam pelatihan-pelatihan dan salah satunya melalui In-House Training penyusunan kelengkapan mengajar. Hal ini mendesak dilakukan karena dari angket yang diberikan kepada guru untuk mengetahui respon Guru terhadap pentingnya memiliki kelengkapan mengajar $57,4 \%$ menyatakan sangat setuju dan $42,6 \%$ setuju artinya seluruh Guru menyatakan setuju/sepakat untuk memiliki kelengkapan mengajar.

Selanjutnya dari angket juga terungkap bahwa pengalaman mengajar, ketidaksesuaian latar belakang pendidikan dan kurangnya pengetahuan tentang penyusunan kelengkapan mengajar menyatakan bahwa $48 \%$ sangat setuju, 33\% setuju 66\% cukup setuju itu artinya bahwa sebagian besar Guru merasa bahwa pengalaman mengajarnya masih minim pada mata pelajaran yang diajarkan, latar belakang pendidikan tidak begitu sesuai dengan mata pelajaran yang diajarkan dan pengetahuan tentang penyusunan kelengkapan mengajar masih kurang.

Lebih lanjut dari angket juga terungkap tentang perlunya diadakan In-House Training dengan data hanya $18 \%$ tidak setuju yang mengindikasikan bahwa hampir seluruh Guru menghendaki adanya In-House Training penyusunan kelengkapan mengajar.

Selain itu angket juga mengungkap bahwa Guru memiliki kemauan yang kuat untuk memiliki kelengkapan mengajar dengan data 33\% menjawab sangat setuju dan $66 \%$ menjawab setuju yang artinya seluruh Guru menyatakan jika diadakan In-House Training maka mereka akan mengikuti dengan sungguh-sungguh dan akan mengaplikasikannya dalam kegiatan pembelajaran.

Atas dasar hal tersebut di atas maka UPT SDN 05 Air Pura Kecamatan Air Pura menyatakan sangat perlu mengadakan In-House Training. Dengan adanya kegiatan In-House Training penyusunan kelengkapan mengajar diharapkan semua guru memiliki kelengkapan mengajar yang lengkap dan mengaplikasikannya dalam proses pembelajaran sehingga proses pembelajaran yang dilakukan akan lebih terarah karena tujuan pembelajaran, materi yang akan diajarkan, metode dan penilaian yang akan digunakan telah direncanakan dengan berbagai pertimbangan.

\section{Metode}

Penelitian Tindakan Sekolah ini dilakukan selama dua bulan yang dimulai dari tanggal 05 Juli 2020 sampai dengan tanggal 07 Agustus 2020. Pada siklus 1 terbagi menjadi empat tahap yaitu tahap persiapan, tahap pelaksanaan tindakan (Inhouse-training Tahap 1), tahap pengumpulan data tahap analisis data (refleksi). Sedangkan pada siklus 2 terbagi menjadi empat tahap pula yaitu tahap perencanaan tindakan, pelaksanaan tindakan (Inhouse-Training Tahap 2), pengumpulan data, analsis data dan diakhiri dengan penyusunan laporan. Penelitian dilakukan di UPT SDN 05 Air Pura Kecamatan Air Pura Penelitian tindakan sekolah ini dilakukan oleh peneliti sendiri Yulmi, S.Pd.SD selaku kepala sekolah pada UPT SDN 05 Air Pura Kecamatan Air Pura . 
Tabel 1. Rencana Tindakan

\begin{tabular}{|c|c|c|c|}
\hline Siklus & Langkah & Rencana Kegiatan & Hasil \\
\hline \multirow[t]{5}{*}{ Siklus 1} & Perencanaan & $\begin{array}{l}\text { - Identifikasi masalah dan } \\
\text { penetapan tindakan } \\
\text { - Perumusan scenario tindakan - } \\
\text { Persiapan tindakan ( Instrumen, } \\
\text { jadwal ) } \\
\text { - Penentuan data dan cara } \\
\text { memperolehnya } \\
\text { - Identifikasi guru-guru yang akan } \\
\text { di } \\
\text { IHT }\end{array}$ & $\begin{array}{l}\text { Masalah kemampuan guru menyusun } \\
\text { kelengkapan mengajar } \\
\text { Tindakan : } \\
\text { In House Training } \\
\text { Apakah pelaksanaan In-House Training dapat } \\
\text { meningkatkan kemampuan guru menyusun } \\
\text { kelengkapan mengajar } \\
\text { Rencana Tindakan: Memeriksa hasil } \\
\text { kelengkapan mengajar guru setelah mengikuti } \\
\text { In House } \\
\text { Training } 1 \\
\text { Melakukan In-House Training } 2 \text { bagi guru } \\
\text { yang belum mampu } \\
\text { menguasai penyusunan kelengkapan mengajar. } \\
\text { Memeriksa kelengkapan mengajar guru }\end{array}$ \\
\hline & Pelaksanaan & $\begin{array}{l}\text { Tindakan dilakukan sesuai rencana } \\
\text { selama } 2 \text { minggu } \\
\text { Tindakan dilakukan melibatkan } \\
\text { semua guru yang ikut In-House } \\
\text { Training }\end{array}$ & Tindakan dapat dilaksanakan sesuai scenario \\
\hline & Pengamatan & $\begin{array}{l}\text { Pengamatan dilakukan dengan } \\
\text { instrument } \\
\text { Seluruh kejadian dalam proses } \\
\text { tindakan dicatat dalam lembar }\end{array}$ & $\begin{array}{l}\text { Data kualitatif dengan catatan peristiwa } \\
\text { selama proses tindakan }\end{array}$ \\
\hline & Observasi & & \\
\hline & Refleksi & $\begin{array}{l}\text { Evaluasi tindakan dan data-data } \\
\text { yang diperoleh } \\
\text { Pertemuan membahas hasil } \\
\text { evaluasi } \\
\text { Merencanakan langkah-langkah } \\
\text { siklus } 2\end{array}$ & $\begin{array}{l}\text { Masalah yang dialami } \\
\text { Peristiwa yang terjadi di luar scenario } \\
\text { Rencana langkahlangkah siklus } 2\end{array}$ \\
\hline \multirow[t]{4}{*}{ Siklus 2} & Perencanaan & $\begin{array}{l}\text { Pelaksanaan In-House Training } \\
\text { Tahap } 2 \\
\text { Rencana langkah tindakan sesuai } \\
\text { hasil refleksi } 1\end{array}$ & \\
\hline & Pelaksanaan & $\begin{array}{l}\text { Pelaksanaan sesuai skenario siklus } \\
2\end{array}$ & \\
\hline & Pengamatan & Sesuai rencana siklus 2 & \\
\hline & Refleksi & Evaluasi sesuai siklus 2 & \\
\hline
\end{tabular}

\section{Hasil dan Pembahasan}

Hasil angket sebelum in-house training dilakukan

Ada sekitar 57.4\% Guru menyadari bahwa sebagai seorang Guru sangat penting memiliki kelengkapan mengajar sebelum melaksanakan proses pembelajaran dan $42.6 \%$ menyatakan penting memiliki kelengkapan mengajar. Hal tersebut berarti secara keseluruhan Guru UPT SDN 05 Air Pura Kecamatan Air Pura menyatakan penting untuk memiliki kelengkapan mengajar.

Hal ini sanghatlah beralasan karena dengan memiliki kelengkapan mengajar yang baik sangat membantu kelancaran dalam proses pembelajaran. Selain itu dengan kelengkapan mengajar akan memberi kesempatan bagi Guru sebagai pendidik untuk merancang pembelajaran sesuai dengan kebutuhan peserta didik, kemampuan peserta didik dan fasilitas yang dimilki sekolah. Demikian pula dengan memiliki kelengkapan mengajar proses pembelajaran yang dilakukan akan lebih terarah, karena tujuan pembelajaran, materi yang akan diajarkan, metode dan penilaian yang digunakan telah dirancang dengan berbagai pertimbangan. 
Hanya sebesar $11.2 \%$ guru yang merasa mata pelajaran yang diajarkan sesuai dengan latar belakang pendidikannya. $44.2 \%$ menyatakan cukup setuju atau ragu-ragu hal ini mungkin Guru merasa mata pelajaran yang diajarkan memang tidak sesuai dengan latar belakang pendidikannya namun mereka merasa mampu mengajarkan mata pelajaran yang diajarkan mungkin karena mata pelajaran yang diajarkan tersebut masih satu rumpun dengan latar belakang pendidikannya. Selebihnya menjawab setuju yang berarti sekitar $44.6 \%$ merasa mengajar tidak sesuai dengan latar belakang pendidikannya. Hal ini terjadi karena UPT SDN 05 Air Pura Kecamatan Air Pura pada awal berdirinya sangat kesulitan mencari tenaga pengajar sehingga pada waktu itu berlaku pepatah tidak ada rotan akarpun jadi.

Sebanyak 44.4\% menyatakan tidak setuju kalau pengalaman mengajarnya dikatakan kurang, dengan kata lain $44.4 \%$ tersebut Guru merasa sudah berpengalaman dalam mengajar sedangkan sisanya $55.6 \%$ Guru merasa dirinya belum berpengalaman mengajar. Hal ini dikarenakan mungkin mereka belum lama diangkat sebagai Guru

Terindikasi sebanyak $\mathbf{1 8 . 0 \%}$ saja Guru merasa tidak perlu In-House Trainiing Penyusunan kelengkapan mengajar hal ini terjadi mungkin karena mereka sudah cukup berpengalaman dalam mengajar sehingga tanpa In-House Training mereka merasa sudah bisa menyusun kelengkapan mengajar. 11.6\% menjawab cukup setuju/ragu-ragu mungkin mereka belum mengetahui dengan jelas tentang materi yang akan disampaikan dalam In-House Training sehingga mereka merasa tidak yakin apakah sudah bisa atau belum bisa materi tersebut.

Sedangkan sisanya $70.0 \%$ menyatakan perlu diadakan In-House Training penyusunan kelengkapan mengajar, Dengan demikian dapat dikatakan bahwa sebagian besar Guru UPT SDN 05 Air Pura Kecamatan Air Pura mengharapkan adanya In-House Training penyusunan kelengkapan mengajar. Hal ini mungkin dikarenakan sebagian besar Guru menyadari bahwa dirinya belum memiliki kelengkapan mengajar dan merasa pengalaman mengajarnya masih kurang serta mata pelajaran yang diajarkan kurang sesuai dengan latar belakang pendidikannya sehingga masih kesulitan dalam menyusun kelengkapan mengajar.

Sebanyak 100\% Guru memiliki motivasi yang tinggi untuk mengikuti InHouse Training dan memiliki keinginan yang kuat untuk membuat kelengkapan mengajar bahkan akan menggunakan kelengkapan mengajar tersebut sebagai penunjang proses pembelajaran. Hal ini berarti seluruh Guru UPT SDN 05 Air Pura Kecamatan Air Pura menyadari pentingnya memiliki kelengkapan mengajar. Dengan demikian InHouse Training penyusunan kelengkapan mengajar memang perlu dilakukan dan mendapat dukungan yang kuat dari para Guru. Dengan demikian diharapkan setelah In-House Training dilakukan kemampuan Guru dalam menyusun kelengkapan mengajar akan meningkat.

Pada siklus 1 berdasarkan data dari tabel diatas dapat dijelaskan bahwa seluruh Guru sudah mulai menyusun kelengkapan mengajar walaupun belum ada seorangpun Guru yang berhasil menyelesaikan kelengkapan mengajar dengan lengkap namun demikian sudah ada satu orang Guru menyelesaikan 100\%, empat orang Guru menyelesaikan 75\% dan yang lainnya masih dibawah $70 \%$ dan yang paling rendah (paling sedikit) berhasil menyusun kelengkapan mengajar adalah sebesar $25 \%$.

Kelengkapan mengajar yang paling banyak terselesaikan pada siklus 1 adalah RPP (Rencana Program Pembelajaran) sebanyak 70\% dan Promes (Program Semester) dan silabus sebesar 40\%. Ini berarti ada kecenderungan Guru memulai menyusun kelengkapan mengajar dari siswa yang akan mengikuti UAS yaitu siswa kelas VI kemungkinan Guru memprioritaskan siswa yang akan menempuh ujian nasional karena dianggap lebih perlu diperhatikan terutama dalam proses belajar mengajar dibanding kelas bawah karena masih dalam tahap penyesuaian sehingga perlu dirancang terlebih dahulu. Kemungkinan lain ada kecenderungan terbiasa memulai sesuatu dari yang akan lulus

Selain data seperti telah dijelaskan diatas, terdapat satu data yang menggambarkan bahwa ada seorang Guru yang baru menyelesaikan kelengkapan mengajar hanya 25\%. Hal ini kemungkinan disebabkan oleh beberapa hal diantaranya, mungkin yang bersangkutan belum lancar menggunakan computer karena dalam mengerjakan tugas tersebut tugas (kelengkapan mengajar) dikumpul dalam bentuk file. Kemungkinan lain yang bersangkutan masih belum begitu paham cara menyusun kelengkapan mengajar tersebut sehingga menjadi lambat dalam mengerjakannya. Atau mungkin juga karena yang bersangkutan tidak meluangkan waktu untuk focus pada penyelesaian tugas tersebut.

Selanjutnya dari tabel terlihat RPP (Rencana Pelaksanaan Pembelajaran) kelas I s/d VI baru mencapai $70 \%$ tersusun oleh Guru. Bahkan ada Guru yang belum menyusun Prota (Program Tahunan) hanya mencapai 40\% kelas I s/d VI dan Promes (Program Semester) untuk mencapai 40\% kelas I s/d VI namun sudah menyusun RPP (Rencana Pelaksanaan Pembelajaran). Hal ini kemungkinan disebabkan karena Guru tersebut 
menganggap bahwa Prota dan Promes untuk kelas II sama saja dengan Prota dan Promes kelas III sehingga bisa saja disusun belakangan yang penting sudah ada RPPnya

Secara umum, pada siklus 1 sudah seluruh Guru mulai menyusun kelengkapan mengajar $(70 \%$ ) namun demikian masih perlu dilakukan tindak lanjut terhadap kegiatan In-House Training tersebut karena indicator keberhasilan In-House Training ini adalah 100\% Guru berhasil menyelesaikan penyusunan kelengkapan mengajar.

Setelah dilakukan refleksi terhadap siklus 1 ternyata ada dua hal yang perlu mendapat perhatian sebagai tindak lanjut yaitu: 1) Prosentase Guru yang menyelesaikan kelengkapan mengajar belum mencapai $100 \%$; $)$ Kelengkapan mengajar yang telah disusun oleh Guru ternyata masih belum sepenuhnya sesuai dengan panduan/pedoman sehingga masih perlu penyempurnaan seperti termuat pada lampiran (tabel refleksi siklus 1)

\section{Hasil yang diperoleh pada Siklus 2.}

Pada siklus 2, In-House Training dilakukan untuk menyempurnakan hasil yang diperoleh pada siklus 1 karena setelah dilakukan refleksi ternyata ada dua hal yang perlu ditingkatkan yaitu: 1) Prosentase Guru yang menyelesaikan kelengkapan mengajar belum mencapai $100 \%$; 2) Kelengkapan mengajar yang telah disusun oleh Guru ternyata masih belum sepenuhnya sesuai dengan yang diharapkan yaitu masih perlu penyempurnaan.

Setelah melalui In-House Training tahap 2 yang dilakukan pada tanggal 02 s/d 03 Agustus 2020 dan diberi waktu tambahan selama 5 hari untuk menyelesaikan tugas penyusunan kelengkapan mengajar yang terdiri dari Prota (Program Tahunan) Promes (Program Semester), Propem (Program Pembelajaran) dan RPP (Rencana Pelaksanaan Pembelajaran), maka hasil dari kegiatan tersebut adalah telah terjadi peningkatan prosentase Guru yang berhasil menyelesaikan penyusunan kelengkapan mengajar yaitu 42,5\% menjadi 95\%. Dari tabel juga terlihat bahwa seluruh Guru telah meningkat kemampuannya dalam menyusun kelengkapan mengajar hal tersebut dapat dilihat dari prosentase kelengkapan mengajar yang diselesaikan pada siklus 1 dan dibandingkan dengan prosentase kelengkapan mengajar yang diselesaikan pada siklus 2. Agar lebih jelas, peningkatan prosentase tersebut seperti pada tabel berikut:

Tabe1 2. Peningkatan Kemampuan Guru dalam Menyusun Kelengkapan Mengajar

\begin{tabular}{lccc}
\hline Nama Guru & $\begin{array}{c}\text { Prosentase pada } \\
\text { Siklus 1 }\end{array}$ & Prosentase pada Siklus & Peningkatan \\
Sarniyati, S.Pd & $75 \%$ & $\mathbf{2}$ & \\
Yulidar, S.Pd.SD & $75 \%$ & $100 \%$ & $25 \%$ \\
Marjasuwati, S.Pd & $50 \%$ & $100 \%$ & $25 \%$ \\
Suherdi, S.Pd.MM & $75 \%$ & $100 \%$ & $25 \%$ \\
Yuaima, S.Pd.SD & $100 \%$ & $100 \%$ & $25 \%$ \\
Yora Prima Putri, S.Pd & $50 \%$ & $100 \%$ & $0 \%$ \\
Emi Sulastri. S.Pd & $25 \%$ & $100 \%$ & $50 \%$ \\
Patma Jumiati, S.Pd & $50 \%$ & $75 \%$ & $50 \%$ \\
Etmiwati, S.Pd & $50 \%$ & $75 \%$ & $25 \%$ \\
Cici Candra Wardani, S.Pd & $75 \%$ & $100 \%$ & $50 \%$ \\
\end{tabular}

Secara umum seluruh Guru telah terjadi peningkatan kemampuan dalam penyusunan kelengkapan mengajar. Namun seperti data yang terlihat pada tabel 8 di atas masih ada dua orang Guru belum berhasil menyelesaikan keseluruhan kelengkapan mengajar yang ditargetkan. Menurut pengamatan penulis, salah satu dari dua orang Guru tersebut dikarenakan belum menguasai keterampilan komputer sehingga dalam mengerjakan tugas tersebut sangat terhambat. Sedangkan seorang lagi, menurut pengamatan penulis sebenarnya cukup menguasai keterampilan komputer namun yang bersangkutan kebetulan pada saat tugas diberikan ada masalah keluarga sehingga belum sempat menyelesaikan tugas yang diberikan.

Tindak lanjut dari siklus 2 adalah: 1) Peserta (Guru) yang belum menguasai keterampilan komputer tersebut dilakukan mentoring dan diberi tambahan waktu untuk menyelesaikan penyusunan kelengkapan mengajar; 2) Peserta yang ada masalah keluarga tersebut diberi kebijakan berupa tambahan waktu untuk menyelesaikan penyusunan kelengkapan mengajar tersebut. 


\section{Simpulan}

Berdasarkan hasil penelitian dan data yang dihimpun serta diinterpretasikan oleh penulis, maka dapat disimpulkan sebagai berikut: 1) Secara keseluruhan Guru UPT SDN 05 Air Pura Kecamatan Air Pura menyatakan penting untuk memiliki kelengkapan mengajar; 2) Sebagian besar Guru UPT SDN 05 Air Pura Kecamatan Air Pura merasa bahwa pengalaman mengajarnya masih minim pada mata pelajaran yang diajarkan, dan pengetahuan tentang penyusunan kelengkapan mengajar masih kurang; 3) Seluruh Guru UPT SDN 05 Air Pura Kecamatan Air Pura menghendaki adanya In-House Training penyusunan kelengkapan mengajar; 4) $100 \%$ Guru memiliki motivasi yang tinggi untuk mengikuti In-House Training dan memiliki keinginan yang kuat untuk membuat kelengkapan mengajar dan akan menggunakan kelengkapan mengajar tersebut sebagai penunjang proses pembelajaran.

Pada Siklus 1 terdapat 42,5\% Guru berhasil menyelesaikan penyusunan kelengkapan mengajar dan pada Siklus 2 terdapat 95\% Guru berhasil menyelesaikan penyusunan kelengkapan mengajar. Jadi ada peningkatan kemampuan Guru dalam menyusun kelengkapan mengajar sebesar 52,5\%. Untuk meningkatkan kemampuan Guru dalam menyusun kelengkapan mengajat pada UPT SDN 05 Air Pura Kecamatan Air Pura dapat dilakukan melalui kegiatan In-House Training.

\section{References}

Rahmat Saripudin, Tuesday, 28 October 2008 14:51, Peningkatan Mutu Pembelajaran. Undang-Undang Republik Indonesia Nomor 20 Tahun 2003 tentang Sistem Pendidikan Nasional Peraturan Pemerintah Republik Indonesia Nomor 19 Tahun 2005 tentang Standar Nasional Pendidikan Undang-Undang Republik Indonesia Nomor 14 Tahun 2005 tentang Guru dan Dosen BSNP. (2007).Model Rencana Pelaksanaan Pembelajaran Kurikulum Tingkat Satuan Pendidikan. Jakarta.Depdiknas.

Dadang Dahlan, In-house Training sebagai Sarana Peningkatan Kualitas Guru Tsanawiyah, file.upi.edu/al.php

Dhony Firmansyah,S.Si. (2008).Karya Tulis disampaikan dalam Pelatihan "Sukses Membuat Proposal Penelitian yang Bermutu" Kumiko Education Centre. 